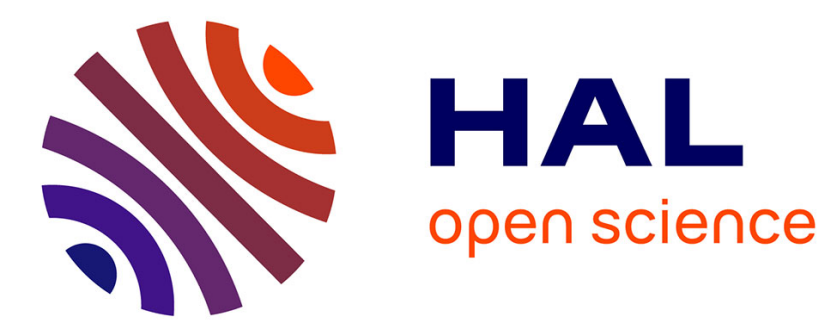

\title{
Non-price rigidity and cost of adjustment
}

Georg Müller, Mark Bergen, Shantanu Dutta, Daniel Levy

\section{To cite this version:}

Georg Müller, Mark Bergen, Shantanu Dutta, Daniel Levy. Non-price rigidity and cost of adjustment. Managerial and Decision Economics, 2007, 28 (7), pp.817-832. 10.1002/mde.1379 . hal-02387449

\section{HAL Id: hal-02387449 \\ https://hal.science/hal-02387449}

Submitted on 2 Dec 2019

HAL is a multi-disciplinary open access archive for the deposit and dissemination of scientific research documents, whether they are published or not. The documents may come from teaching and research institutions in France or abroad, or from public or private research centers.
L'archive ouverte pluridisciplinaire HAL, est destinée au dépôt et à la diffusion de documents scientifiques de niveau recherche, publiés ou non, émanant des établissements d'enseignement et de recherche français ou étrangers, des laboratoires publics ou privés. 


\title{
Non-Price Rigidity and Cost of Adjustment*
}

\author{
Georg Müller ${ }^{\mathrm{a}}$, Mark Bergen ${ }^{\mathrm{b}}$, Shantanu Dutta $^{\mathrm{c}}$ and Daniel Levy ${ }^{\mathrm{d},}$ * \\ ${ }^{a}$ Strategic Pricing Group, 18W140 Butterfield Rd, Oakbrook Terrace, IL 60181, USA \\ ${ }^{\mathrm{b}}$ Carlson School of Management, University of Minnesota, Minneapolis, MN 55455, \\ USA \\ ${ }^{\mathrm{c}}$ Marshall School of Business, University of Southern California, Los Angeles, CA \\ 90089, USA \\ ${ }^{\mathrm{d}}$ Department of Economics, Bar-Ilan University, Ramat-Gan 52900, ISRAEL
}

\begin{abstract}
There has been increasing interest in understanding how firms undertake nonprice adjustment activities, especially in situations where prices may be rigid despite changes in market conditions. Using scanner price data for over 4,500 different food products from a large US supermarket chain, we document periods of rigidity in product additions and deletions: new products are less likely to be introduced, and existing products are less likely to be discontinued during holiday periods than throughout the rest of the year. We argue that this is due to higher costs of undertaking these kinds of product assortment activities during holiday periods. We discuss how this relates to the exiting literature on non-price adjustment and price rigidity.
\end{abstract}

Last Revision: September 5, 2006

JEL Codes: D21, L20, M21, M31, L81

Key Words: non-price adjustment mechanism, cost of adjustment, price rigidity, holiday, product assortment, product introduction, product deletion, sticky price, rigid price, menu cost

\section{* Correspondence:}

Department of Economics, Bar-Ilan University, Ramat-Gan 52900, ISRAEL.

Tel: +972-3-531-8331; Fax: +972-3-535-3180; Email: Levyda@mail.biu.ac.il. 


\section{INTRODUCTION}

There is a growing interest in understanding how firms undertake non-price adjustment activities (Blinder et. al., 1998; Economides, 1998; Hammer, 1999; Symeonidis, 2000; Clay, et al. 2002). This is especially true in situations where prices are found to be rigid. This is because when nominal prices are rigid, firms may be adjusting to changes in market conditions by using non-price activities. If that is the case, then perhaps the nominal price rigidity is not as important because it does not necessarily lead to allocative inefficiency.

Firms have various non-price adjustment options. For example, Carlton (1983, 1985, 1986, and 1989) and Carlton and Perloff (1994) suggest that these non-price adjustment mechanisms could include changes in product quality or service quality. Another margin of adjustment is the product's quantity, as in Danziger (2001), Andersen and Toulemonde (2004), Levy and Young (2004, 2005) and Young and Levy (2006). Still another margin of adjustment is the product's delivery time, such as forcing customers to wait in line (Epstein, 2006), delivering a mail-order product using ground service instead of next-day-air, or forcing customers to return to the store next day because of a stock out. Finally, firms can change the product's delivery place, such as by offering the product's delivery to customers' homes, or asking them to come to the establishment to pick up the products. ${ }^{1}$

In this paper we explore another type of non-price adjustment activity in which retail supermarkets are routinely engaged. We study the timing of a key non-price decision undertaken by retailers - the introduction of new products and deletion of existing products. Using scanner price data from a large mid-western supermarket chain, we study when and how often product assortments are changed. We study the phenomenon in the context of holiday periods, a time period during which increased price rigidity has been documented by Müller, et al. (2005 and 2006), and during which retailers experience a substantial increase in demand (Chevalier, et al., 2003). ${ }^{2}$ Müller et

\footnotetext{
${ }^{1}$ See Levy (1999) for some anecdotal evidence on the popularity of quality and quantity adjustments at some Atlanta area restaurants and establishments in response to changes in supply and demand conditions. ${ }^{2}$ It should be noted that the studies by Müller, et al. (2005, 2006) and Chevalier, et al. (2003) use the same Dominick's data set. Also, note that by "holiday period" we do not mean a period of "slackness." Rather, by "holiday periods" we are referring to the religious and national holidays in the US, the periods during which
} 
al. (2005) report that retail supermarkets reduce the frequency of price adjustments during holiday periods in comparison to the non-holiday periods. Müller et al. (2006) find that the prices of private label products exhibit greater rigidity in comparison to the nationally branded products.

Given these findings of the holiday-period nominal price rigidity, our goal in this paper is to use the same data set to explore the frequency of changes the retailer undertakes in product assortment-product introductions and deletions-as a possible margin of adjustment. We find that the frequency of product introductions and deletions declines during holiday periods in comparison to the rest of the year. We further refine our analysis by looking at pre-priced products and find that these types of products are also introduced and deleted less frequently during holiday periods in comparison to the rest of the year.

We argue that this reduced frequency in the retailer's holiday period non-price activity is due to the increased costs of undertaking any sort of labor-intensive activities such as those associated with a change in product assortment. There are many laborintensive activities undertaken to run a retail grocery store. These activities include manning a cash register, restocking shelves, or performing price changes (Müller, et al., 2005). Changing product assortments is particularly labor intensive because it requires the rearrangement of shelf layouts to accommodate new items being added to the assortment, and closing gaps in shelf displays left by discontinued items. In addition, many price change activities have to be expanded to include these products. Moreover, in many cases, new products require substantial and often quite aggressive promotional support.

This implies that the use of non-price activities depends on the costs of non-price adjustment much as price adjustment depends on the costs of price adjustment. In other words, the functioning of the market adjustment mechanism may depend on both costs of price adjustment and costs of adjusting other — that is, non-price-attributes of the product. We discuss how this relates to the exiting literature on non-price adjustment mechanisms, pricing during holiday periods, price rigidity, and cost of price adjustment.

the demand reaches its peak. Examples include the Thanksgiving holiday, the Christmas holiday, the July $4^{\text {th }}$, the Easter holiday, etc. 
The paper is organized as follows. In the next section, we describe the scanner transaction price data set we use. In the third section, we report the results of the data analysis. In the fourth section, we discuss the role of adjustment costs in determining the retailer's decision on product assortment, in terms of new product introductions and old product deletions, during holiday periods. We also analyze the data on pre-price product introductions and deletions. The paper ends in the fifth section where we offer final conclusions.

\section{DATA}

We use scanner data set from Dominick’s, a large Mid-western supermarket chain in the larger Chicago metropolitan area, operating 94 stores with a market share of about 25 percent. $^{3}$ According to Levy, at al. $(1997,1998,2002)$ and Dutta, et al. $(1999,2002)$, large multi-store U.S. Supermarket chains of this type made up about $\$ 310.1$ billion in total annual sales in 1992, which was 86.3 percent of the total retail grocery sales. In 1999, the retail grocery sales have reached $\$ 435$ billion, according to Chevalier, et al. (2003). Thus the chain we study is a representative of a major class of the retail food industry. Moreover, Dominick's type multi-store supermarket chains' sales constitute about 14 percent of the total retail sales of about $\$ 2,250$ billion in the US. Because the retail sales account for about 9.3 percent of the GDP, our data set is a representative of as much as 1.28 percent of the GDP, which is substantial. Thus the market we are studying has a quantitative economic significance, as well.

The original Dominick's data consist of up to 400 weekly observations of transaction prices in 29 different categories, covering the period from September 14, 1989 to May 8, 1997. For many products, however, the data are missing for many weeks because they were not always recorded. The length of individual product price series, therefore, varies depending on when the data collection for the specific category began and ended. We should note that Dominick's UPC (Universal Product Code)-level database does not include all products the chain sells. The database we use represents approximately 30 percent of Dominick's revenues. The data come from the chain's 
scanner database, which contains the retail transaction prices of the products by each SKU (Stock Keeping Unit) code, which enables us determine when a new product is introduced or when an old product is discontinued.

The retail prices are the actual transaction prices: the price customers paid at the cash register each week. If the item was on sale, then the price data we have reflect the sale price. Although the retail prices are set on a chain-wide basis at the corporate headquarters of Dominick's, there may still be some price variation across the stores depending on the competitive market structure in and around the location of the stores (Barsky, et al., 2003). According to Chevalier, et al. (2003), Dominick’s maintains three such price-zones. Thus, for example, if a particular store of the chain is located in the vicinity of a Cub Food store, then the store may be designated a "Cub-fighter" and as such, it may pursue a more aggressive pricing policy in comparison to the stores located in other zones.

The subset of the data we use consists of 4,532 products in 18 product categories. In Table 1 we list the product categories and the number of products for which data were available in each category. Our sample covers a four-year period, from the week of September 14-20, 1989 to the week of September 16-22, 1993, a total of 210 weeks, where a week is defined from Thursday through Wednesday. The scanner database contains weekly data on all products within a category sold at each of the 94 stores of the supermarket chain. The products are the actual products available for sale at the store that week. The data we use for the analysis come from six stores of the chain that face similar competitive environments. ${ }^{4}$ In total, therefore, we use 4,532 $\times 6=27,192$ price series.

We focus on the decision of new product additions and old product deletions undertaken by this chain during the sample period. We are able to identify a product as added or deleted because each product has a unique UPC code attached to it in the data set. If an old UPC code disappears from the data set then we know that the product has been deleted from the product assortment. Likewise, if a new UPC appears in the data,

\footnotetext{
3 The data are available through the University of Chicago's marketing department web page at www.gsb.uchicago.edu/research/mkt/MarketingHomePage.html. Below we describe the data only briefly. For more information about the data, see Müller, et al. (2005) and Barsky, et al. (2003).

${ }^{4}$ We also analyzed the data for three stores in the chain that faced greater price competition. We find that all the results reported in this paper for the six stores also hold for the more price competitive stores.

Therefore, to save space we do not report these results in the paper.
} 
then we know that it is a new product introduced in the store.

We also have information on a less frequently used, but very interesting, form of product addition and deletion-pre-priced products. These are product offerings where the price is part of the product package. This is a form of manufacturer's suggested retail pricing. Since the customer sees the suggested pre-printed price, the retailer will be unable to charge a price higher than the pre-printed price. ${ }^{5}$

Thanksgiving and Christmas were chosen as the holiday periods of interest for several reasons. First, Warner and Barsky (1995) suggest that these two holidays are the busiest period in the durable and semi-durable goods market. Second, Chevalier, et al. (2003), who also use Dominick’s data set, conclude that Christmas and Thanksgiving holidays represent the overall peak shopping periods for Dominick’s. Third, conversations with supermarket managers suggest that the Thanksgiving-Christmas holiday period constitutes the busiest shopping period in their stores. In fact, managers described the time just before Thanksgiving through the end of Christmas as "the holiday season.” Thus, in the analysis that follows, the holiday weeks are defined as the week before Thanksgiving through the week of Christmas, for a total of six-week period in each year.

We shall note that we also ran the analyses for other combinations of holiday weeks, including two weeks before Christmas and two weeks after Christmas, or focusing on each holiday individually. Our results were similar for all of the alternative combinations we ran. In addition, we run a similar analysis by including other holiday periods such as Memorial Day, $4^{\text {th }}$ of July, and Labor Day, but we found that the holiday period rigidity results we report primarily hold for the Thanksgiving and the Christmas holidays.

\section{EMPIRICAL FINDINGS}

Our data allow us to examine whether product introductions and deletions tend to vary between holiday and non-holiday periods. We first offer evidence on the variation in

\footnotetext{
${ }^{5}$ It turns out that pre-pricing is typically used in settings where the retailer has incentive to sell the product at a higher price. Manufacturers try to prevent it by printing the suggested retail price on the product itself. This effectively ensures that the actual transaction price to the consumer will be the suggested pre-printed price.
} 
the introduction and deletion of products across holiday and non-holiday periods. We then explore the behavior of introduction and deletion of the pre-priced products.

\section{Analysis of Product Introductions and Deletions}

To test whether product introductions and deletions vary between holiday and non-holiday periods, we use two different analyses. First we consider the probability that a product is introduced or deleted during a holiday period. Using the data on product introduction and deletion dates, we estimated two logit regression models. In the first model, the logit of product introduction is regressed against the "Holiday" dummy variable,

(1) $\log \left(\frac{p_{t}}{1-p_{t}}\right)=\alpha+\beta$ Holiday $_{t}$,

where $p_{t}$ denotes the probability of a product introduction.

In the second model, the logit of product deletion is regressed against the holiday dummy variable,

$$
\log \left(\frac{p_{t}}{1-p_{t}}\right)=\gamma+\delta \text { Holiday }_{t}
$$

where $p_{t}$ denotes the probability of a product deletion. In both models, the "Holiday" variable attains the value 1 if week $t$ is a holiday week, and 0 otherwise. The parameters $\beta$ and $\delta$ are the measures of interest; a $\beta<0(\delta<0)$ implies that product introduction (deletion) is less likely during holiday periods. We have excluded weeks 1 and 210 from the analysis because they are the beginning and the end weeks of the sample period. Since all products are "introduced" and "deleted" on these dates, we remove these data end-points to avoid biases. Thus, the analysis includes only those products that were introduced or deleted during the period of weeks 2-209 of the sample period.

The above logit models were estimated using the method of maximum lilelihood. The estimation results are presented in Table 2. The figures in the table suggest that the 
holiday periods tend to have significantly fewer product introductions (columns 1 and 2) as well as fewer product deletions (columns 3 and 4 ) in comparison to the rest of the year. The coefficient estimates in columns 1 and 3 are all negative and statistically significant, with the exception of the paper towels category. Moreover, the $p$-values in columns 2 and 4 indicate that most of the coefficients are significant at 1 percent level. Thus, the logit regression analysis suggests that the retailer is more likely to introduce and delete fewer products during holiday weeks in comparison to the rest of the year.

Because the holiday period constitutes less than 12 percent of a year, a comparison of the absolute number of product introductions and deletions across the holiday and non-holiday periods may not be as persuasive. Another way of analyzing product introductions and deletions, therefore, is to consider the actual number of products introduced and deleted during the holiday weeks and see whether it is statistically indifferent from the introduction and deletion figures we would obtain if the odds were even. If the introductions and deletions occurred uniformly with equal probability throughout the year, then the probability that an introduction occurs during a holiday period is 0.1154 , which is the ratio of the number of holiday weeks, 6 , to the total number of weeks in the year, 52. Thus, our goal is to compare the actual proportion of product introductions and deletions to even odds (11.5 percent) of product introductions and deletions. ${ }^{6}$

Table 3 identifies by product category the number of product additions and deletions made during the duration of this study. There are thousands of such product adjustments, but they still only make up a small percentage of the total products on the shelves in these stores. In the table we report the total number of products introduced (column 1) and deleted (column 3) during the entire period along with the number of products introduced and deleted during the holiday weeks only (columns 2 and 4, respectively) in each category. Next we compute the proportion of the holiday period product introductions (column 5 = column 2/column 1) and compare it to the even odds of product introductions (column 6). In the last two columns we compute the proportion of the holiday period product deletions (column $7=$ column 4/column 3) and compare it to the even odds of product deletions (column 8).

\footnotetext{
${ }^{6}$ As before, the weeks 1 and 210 have been excluded from the analysis to avoid bias.
} 
As the figures in Table 3 (column 5) indicate, the actual proportion of the holiday period product introductions is less than the even odds of 11.5 percent in all but one category, the exception being the paper towels category. Further, for 15 of these 17 categories, these differences are statistically significant at 1 percent level. These findings are reproduced on Figure 1 to allow easier cross-category comparison.

Similarly, the figures in column 7 indicate that the actual proportion of the holiday period product deletions is less than the even odds of 11.5 percent in all but one category, the exception, again, being the paper towels category. Further, for all 17 categories, the differences are statistically significant at 1 percent level. These findings are also reproduced in Figure 2.

Finally, when we aggregate across all 18 categories, we find that the proportion of the holiday period product introductions and deletions are 5 percent and 4 percent, respectively, in contrast to the even odds of 11.5 percent (with $t$-statistics of -14.33 and 22.85, respectively, both significant at the 1 percent level).

Thus, the tests of the hypotheses of random introduction and deletion dates suggests that, with the exception of the paper towels category, product introductions and deletions are far less likely during the holiday periods in comparison to the rest of the year. A plausible explanation for the unusual behavior of the paper towel category, which actually experiences an increase in product introductions and deletions, seems to be the practice of the retailers in holidays to market paper towels with holiday themes. This would significantly raise the marginal benefit of adjusting product assortment in the paper towels category during these periods.

\section{Analysis of Pre-Priced Product Introductions and Deletions}

In many categories, another form of product introduction and deletion by manufacturers are pre-priced packaging. These are product offerings where the price is part of the product package. This is a form of manufacturer's suggested retail pricing and usually it is the actual price a retailer charges.

This type of pre-pricing may be used for several reasons. Often, pre-pricing is used in settings where the retailer has incentive to sell the product at a higher price. Manufacturers try to prevent it by printing the suggested retail price on the product itself. 
This effectively ensures that the actual transaction price to the consumer will not exceed the suggested pre-printed price. ${ }^{7}$

Another possible purpose of pre-pricing is to frame a product price in relation to a reference price such as in the cars market, where the manufacturers suggested retail price sticker attached to all new cars serve as a starting point as well as a point of reference during the haggling and negotiation over the car's final price. Finally, pre-pricing may be efficient: it can save the cost of posting a shelf price tag, or the cost of attaching an individual price sticker such as those required in states that have item pricing law requirements (Bergen, et al., 2006). This will be true if, for example, the marginal cost of printing a manufacturer's suggested retail price on each individual package is zero or close to zero simply because a lot of other information is being printed on the product package anyway during the manufacturing and/or packaging process.

In Table 4, we list the number of pre-priced products added and deleted, by product category, during this study. Comparing the number of introductions and deletions in Tables 3 and 4, one can see that the activity on pre-priced products is substantially smaller (by an order of magnitude) in comparison to the standard product additions and deletions.

To test whether this kind of activity varied between holiday and non-holiday periods we consider whether pre-priced products were less likely to be introduced or

\footnotetext{
${ }^{7}$ A recent study by Levy and Young (2004) documents the effectiveness of using a similar strategy in a different setting. According to their study, the retail price of $6.5 \mathrm{oz}$ serving of Coca-Cola from the fountain or in a bottle, remained 5\& from the first day it was introduced to the American public in 1886, until 1959. In other word, Coke's price has remained unchanged for over 70 years! It turns out that one of the effective methods the Coca-Cola Company used to ensure that no retailer charged a price above $5 \mathbb{\$}$, the company included " $5 \notin "$ in all print ads. In addition, " $5 \notin$ " was printed on a large proportion of the millions and millions of various types of promotional material the company was distributing to the retailers and to the end customers through the local bottlers. These promotional material included match books, pencils, clocks, doilies, wall lithograph signs, trays, thermometers, Japanese fans, calendars, baseball score cards, etc. According to Young and Levy (2006), during 1913 alone, the Company distributed 2 million trays for soda fountains, 1 million Japanese fans, 1 million calendars, 10 million match books, 50 million doilies, etc. The strategy of nationally advertising the Coke's nickel price in millions of print ads and on promotional material made it impossible for any retailer to charge a price higher than 5\$. For example, according to the January 1951 issue of the Fortune magazine ("The Nickel Drink is Groggy," pp. 78-79, pp. 129-131), Paul A. Gilham, Coca Cola bottler at Alexandria, Louisiana (also described as "a price-forprofit tinkerer"), in 1947 increased the Coca-Cola per case price to his dealers (i.e., the retailers) from $80 \varnothing$ (a case of Coca-Cola contained 24 6.5-oz bottles) to \$1. But after just two months Gilham had to cut the price back to $80 \AA$. According to the Fortune article, about $40 \%$ of the retailers tried to pass the higher costs onto their customers, but the customers threatened to take all their business elsewhere, arguing (p. 129), "Everybody knows Coke sells for a nickel—Look at the back of this week's Life."
} 
deleted during the holiday period. To test this hypothesis, we again calculate the probability that a pre-priced item is introduced during a holiday period against the evenodds of 6/52 $=11.54$ percent. The results are given in Table 4 . It turns out that of the 18 product categories we study, only 8 categories contained pre-priced products. But for four of the categories a statistical testing is not possible because of the zero holiday-period introductions and deletions. Overall, across these 8 categories, 132 pre-priced products were introduced during the 208-week period. ${ }^{8}$ As Table 4 indicates, of these 132 introductions, only 9, which means that only 7 percent occurred during the holiday weeks. Thus, compared to even-odds of 11.54 percent, there is a significantly lower likelihood of new pre-priced product introductions during the holidays (with $t=-2.15$, which is significant at 1 percent level) in comparison to the rest of the year. Similarly, we find a total of 122 deletions during the 208-week period, of which only 7, that is only 6 percent, occurred during the holiday period. ${ }^{9}$ Compared to even-odds of 11.54 percent, there is a significantly lower likelihood of pre-priced product deletions during the holiday period (with $t=-2.76$, which is significant at 1 percent level) in comparison to the rest of the year.

\section{Costs of Adjusting Product Assortment during Holidays}

Given the consistent evidence that product assortment activity in terms of product additions and deletions is more rigid during holiday periods in comparison to the rest of the year, the next issue is exploring explanations for this rigidity. Our explanation for this behavior is that during holiday periods the opportunity costs associated with product adjustment activities are higher. This conclusion is consistent with the findings reported by Müller, et al. (2005), who argue that costs of price adjustment increase during holiday periods. It is also consistent with our discussions with retail managers, who emphasized the higher physical, managerial, and customer costs associated with these kinds of activities during holidays.

New product introductions and deletions (as well as introductions and deletions of

\footnotetext{
${ }^{8}$ The end-point weeks of the sample period are again excluded to avoid bias.

${ }^{9}$ Note again the result for paper towels: the proportion of holiday period deleted products, 22 percent, exceeds the even odds of 11.5 percent. We should note, however, that because of the small number of
} 
pre-priced items) can entail significant costs at the retail level. According to Levy and Weitz (2001, p. 566), the decision how to allocate the limited shelf space to various departments, categories, and items is “... one of store planners' and category managers' most complicated and difficult decisions.”

New product introductions are quite labor-intensive and costly for the retailer because shelf layouts (plan-o-grams) have to be re-arranged to accommodate the addition (Berman and Evans, 1995). This requires a great deal of employee time and effort to take the old products off the shelf, add new products, and rearrange the shelf to match the new plan-o-gram. Indeed, the costs to the retailer are so high that in many product categories, the retailer charges the manufacturers slotting allowances to help defray the costs of adding a new product to an assortment that already contains thousands of items. For instance, in 1996 the average supermarket carried about 31,000 SKU (unit which signifies the number of products), an increase of 20-25 percent over five years (Kahn and McAlister, 1997). This proliferation of new products in almost all product categories has led to significant competition among manufacturers who are clamoring for limited retail shelf space.

Practitioners offer plenty of anecdotal evidence confirming this argument. For example, a recent Wall Street Journal article succinctly summarized the choice that many supermarket managers face when deciding which products to carry: "You are a supermarket manager wondering how to choose which items to stock among the hundreds of thousands available, and how to display them, in order to maximize your return from a finite amount of square footage. Not only that, but manufacturers are continuously trying to persuade you to make space for new products. How do you know they've done the proper research and advertising to give the product a fighting chance?” (Source: “We Love Slotting Fees,” by Holman W. Jenkins, Jr., The Wall Street Journal, Wednesday, September 22, 1999, p. A23.)

The cost of a new product introduction to retailers can be further increased by manufacturer demands that the retailers implement some promotional pricing activity for the new product (Buzzell, Quelch, and Salmon, 1990). In order to implement promotional 
pricing activities, retailers have to allocate more labor time to ensure that the price on the shelf matches the promotional price and the price posted on special displays used during the promotion (Levy, et al., 1997, 1998, and Dutta, et al., 1999).

New product introductions can also be costly to retailers if they do not sell. The decision what items to carry is further complicated by the fact that these decisions need to take account the inventory holding costs. For example, according to Levy and Weitz (2001, p. 567), “How will the planned inventory turnover and the resulting stock-to-sales ratio affect how many SKUs will normally be carried in stock? Recognize that (as in the merchandise budget plan) monthly inventory levels vary according to seasonal demands, holidays and so on. Category managers and store planners must allocate space based on these seasonal needs rather than yearly averages. They must also estimate the proportion of merchandise kept on display versus backup stock. Merchandise kept as backup stock in a storage area takes much less room.”

Manufacturers recognize this cost to retailers and offer generous introductory trade allowances and even up-front fixed payments (Oliver and Farris, 1989) to overcome initial retailer resistance. Despite these generous trade allowances, grocery chains regularly drop products that are not selling well. A survey of grocery purchasing managers found that 92 percent will drop products (SKU's) in a category if the products are slow to move and do not meet their expectations even if manufacturers offer generous allowances (Oliver and Farris, 1989). In fact, the specific supermarket chain we study adjusts shelf space allocation regularly throughout the year and adds and drops product lines based on its assessment of local customer demand and other market factors (Berman and Evans, 1995).

Similarly, product deletions are also quite costly for the retailer for at least two reasons. First, extra labor has to be devoted to rearranging the shelf space and getting rid of the old inventory to ensure that there are no empty spaces on the shelves. Second, labor costs have to be incurred to rearrange the price labels to make sure they match the new items on the shelves. Given the findings of Levy, et al. $(1997,1998)$ and Dutta, et al. (1999), these steps would require retailers to allocate significant in-store labor time towards these tasks.

Another cost associated with product introductions and deletions is mistakes that 
occur during the process. When mistakes are made during the price change process, they create problems such as longer lines at cash registers, time spent checking and rectifying the mistakes, and dissatisfaction among customers. ${ }^{10}$

\section{Increased Opportunity Costs of Adjustment during Holiday Periods}

For retail chains, the costs of product introductions and deletions are higher during holiday periods. During the holiday season the opportunity cost of using employee time to add and delete products rather than perform other tasks rises substantially, increasing costs of price adjustment for the stores. This is due to the larger volume of customer traffic moving through stores during holiday periods, as documented by Warner and Barsky (1995) and Chevalier, et al. (2003). This increased customer traffic necessitates a focus on more urgent activities such as the tasks of running the cash registers, restocking the shelves, cleaning, handling customers' questions and inquiries, bagging, etc. These are critical to maintaining the "goodwill” of customers (Oliver and Farris, 1989), and the greater shopping activity in the holiday season forces retailers to undertake more of these activities. We believe that these higher opportunity costs of adjustment lead to greater rigidity in new product introductions and deletions during holiday periods.

The conversations we had with store managers confirmed the existence of higher costs of adjustment during holidays. For example, Brett Drey, a retail manager at both drugstores and mass merchandisers, states: “It's a madhouse during the holidays. There is no time to do anything that is marginal or incremental-you have to focus on the essential issues, keeping items in stock, keeping the registers manned, and making the store presentable. The key is to manage the flow of goods and customers through the store."

In practice grocery managers try to solve the problem of the increased labor need by paying overtime, or by hiring temporary workers (which is often difficult because of the shortage of the available temporary labor force during the Thanksgiving/Christmas

\footnotetext{
${ }^{10}$ The costs of mistakes made up a significant portion of the costs of price adjustment reported in Levy, et al. $(1997,1998)$.
} 
holiday period) at a premium. They may also move "expensive resources” such as more skilled workers and even store managers, toward these more urgent tasks. This kind of expensive temporary labor hiring, and the relocation of the existing work force during holiday periods, leads to an increase in the opportunity cost of activities such as product additions and deletions. The rise in the opportunity cost, we argue, makes it rational to not engage in activities such as new product introductions and deletions, or in frequent price changes (Müller, et al., 2005), during holiday periods.

In addition, product introductions and deletions may increase the cost incurred by the retailer due to increased frequency of pricing mistakes caused by these activities. These mistakes occur because often the posted prices do not match the scanner price. Based on the thick market argument of Warner and Barsky (1995), the costs of pricing mistakes may increase further during holidays. Therefore, manufacturers taking these retail costs into account are less likely to introduce new products during the holidays.

This is likely to be also true for introductions and deletions of pre-priced products. When a manufacturer introduces a pre-priced product, it is essentially imposing a price change upon the retailer. The retailer has no option of setting a price higher than the one printed on the package. Consequently, an introduction of a pre-priced product imposes a cost on retail stores (Levy, et al., 1998) because the store employees first have to go to the shelves and check to see if the prices stated on the current shelf price tag are the same as on the product package. If the prices do not match, then the old label has to be destroyed and a new label needs to be prepared and installed. This process also increases the likelihood of price mistakes, which imposes additional costs on the retailer. The resulting increase in the labor, managerial, and customer costs can be significant, making the costs of pre-priced items' introduction even higher during holidays. These increased costs likely lead to greater rigidity in the introduction and deletion of pre-priced items during the holiday period. ${ }^{12}$

The specific form of non-price rigidity we are documenting in this paper cannot be explained by many commonly used explanations of price rigidity (Blinder et al.,

\footnotetext{
${ }^{11}$ We have even observed some retail managers discussing the possibility of doing in-store product experiments laugh at the idea that they be conducted during holiday periods because of the hectic nature of the season.
} 
1998). For example, it is unlikely that the benefits of adding new products or of deleting slow moving products diminish for retailers during the holidays. If at all, based on the thick market argument of Warner and Barsky (1995), these benefits may actually be higher. This may explain our findings in the category of paper towels, where we did observe greater product additions and deletions during holiday periods. In this category there are seasonal holiday designs, making the benefit of adjusting the assortment of these products particularly higher during holiday periods. But certainly, based on benefits, a priori there is no reason to expect decreases in the number of new product introductions or deletions during holiday periods in comparison to the rest of the year.

Similarly, holiday periods are too short to exhibit large-scale variation in the industry structure or market structure, which has been identified as one of the key reasons for variation in the extent of price rigidity across products, industries and markets (Gordon, 1990). Therefore theories that rely on variation in the market structure are unlikely to explain our findings. Likewise alternate explanations such as variation in the nature of long-term relationships or in contractual arrangements, or variation in product quality, cannot explain the product activities we document because it is unlikely that these aspects of the market environment will vary between holiday and non-holiday periods.

\section{CONCLUSION}

In sum, the analysis of a large US retail supermarket scanner data reveals an interesting fact: firms undertake fewer product additions and deletions during holiday periods in comparison to the non-holiday periods. Our explanation for this behavior of the retailer is that the opportunity cost of adjusting the assortment and the variety of products are higher during holiday periods.

The study of variation in price rigidity across dimensions such as time, markets and products has a long history in economics. Many authors have called for more studies in this area, arguing that understanding the reasons for this variation is crucial for the theory of price adjustment (Gordon, 1990).

\footnotetext{
${ }^{12}$ We should note, however, that the number of the pre-priced products introduced and deleted is quite small proportionally.
} 
In this paper we are documenting a variation in the extent of the rigidity of retailers' non-price activities, which parallels the variation in price rigidity earlier studies have documented. For example, Bedrossian and Moschos (1988), Geroski (1992), Domberger (1979), Hannan and Berger (1991), and Neumark and Sharpe (1993) document variation in price rigidity that is explained by variation in the market structure. Caucutt, et al. (1995) relate variation in price rigidity to the extent of product durability. Dutta, et al. (2002) document variation in price rigidity across channels, spot-towholesale versus wholesale-to-retail. Levy et al. (2002) study the effect of exogenous cost shocks on prices. They document variation in price rigidity that can be explained by variation in the size of the cost shocks, in the extent of the persistence of the shocks, and in the amount of information various market participants have about the shocks.

Our findings here suggest that heterogeneities are present in retailers' non-price activities as well. Our explanation of the findings is based on costs of adjustment argument. There is a large theoretical and empirical literature on costs of price adjustment. ${ }^{13}$ In this paper we extend the theory of cost of price adjustment by applying it to the retailers' non-price activities as well. This suggests a more important role for costs of adjustment theories in studying and understanding firms holiday period as well as perhaps other activities than the existing literature recognizes.

Our findings indicate that firms act differently during holiday periods in comparison to non-holiday periods. A similar conclusion has been drawn also by Warner and Barsky (1995), Pashigian and Bowen (1991), Chevalier, et al. (2003), and Müller et al. (2005, 2006). For example, Müller, et al. (2006) use the same data set as here to document a greater degree of holiday period price rigidity of private label products in comparison to nationally branded products. They suggest that the relative rigidity of private label product prices may be due to the increased emphasis on social consumption during holiday periods, which leads to an increase in the value of nationally branded products relative to store brand products. National brand products may be more valuable during holiday periods because they are consumed in social settings, with friends and

\footnotetext{
${ }^{13}$ See, for example, Mankiw (1985), Rotemberg (1982), Blanchard and Kiyotaki (1987), Caplin and Spulber (1987), Caplin (1993), Ball and Mankiw (1994, 1995), Ball and Romer (1991), Slade (1998), Caplin and Leahy (1991), and Danziger (1999), Levy, et al. (1997, 1998), Dutta, et al. (1999), Bergen, et al. (2003), Zbaracki, et al. (2004, 2006), and Levy and Young (2004).
} 
family members. People want to leave positive impressions, and show they care, by buying the "best," or at least do not want to appear cheap. Thus, social consumption that takes place during holiday-periods decreases the value of private label products relative to nationally branded products. This makes a price change for private label products less effective during holiday periods. This will be particularly true if costs of price adjustment are indeed higher during holidays, as suggested by Müller, et al. (2005).

But these studies focus on the firms' price adjustment policy. Here we find evidence that firms' non-price activities also vary between holiday and non-holiday periods. This is not surprising given the differences in demand and costs during these periods as documented by the above authors. Nonetheless, our finding is important because it forces us to apply a similar logic to all firm choice variables during holidays, not just to the price.

While we do not have direct data on the nature of the cost of adjustment a retailer must incur to adjust its product assortment, the referee has made an interesting suggestion that unlike the cost of adjusting price, which in some retail settings was found to be mostly fixed as the menu cost models typically assume (see, for example, Levy, et al., 1997 and 1998, and Dutta, et al., 1999), the cost of adjusting product assortment might have a significant convex component. That is because adjusting product assortment might be viewed as similar to quantity adjustment, often requiring the use overtime labor, or perhaps even hiring and training new employees. Also, inventory adjustment costs might be quadratic.

It is interesting to compare our results with those of Müller, et al. (2005). They document increased price rigidity during holiday periods, and argue that this may be due to increases in the costs of price adjustment due to the higher opportunity costs of employee and management time during the holiday periods. We find that some non-price variables are also more rigid during holiday periods. Thus patterns of both price rigidity and non-price rigidity occur at the same time in this dataset. We also argue that the nonprice rigidity is due to increased opportunity cost of these non-price activities during holiday periods. Thus, the factors that make the holiday period price adjustments costly seem to play a role in making non-price adjustment costly as well.

Our explanation, therefore, points towards the benefits of explicit consideration of 
costs of adjustment as a potential determinant of firms' non-price related activities (Caplin and Leahy, 1995). This suggests that we should not be quick to assume that nonprice activities will necessarily be chosen by firms to adjust to changes in market conditions when prices fail to adjust.

More generally, this analysis suggests that we should consider more than the product's price when thinking about a seller's reaction to changes in market conditions. Besides (or instead of) the price, the seller may choose to adjust some other dimension of the product such as the product's quantity, quality, the product variety, delivery time, delivery place, etc (Carlton, 1983 and 1985). Moreover, the idea of cost of adjustment may be fruitfully explored along with each one of the product attributes listed above.

Further, a more complete analysis should consider the costs of price adjustment along with costs of adjusting along other dimensions of the product. For example, it may be valuable to focus on the relative costs of adjustments, to better understand when and why prices or other non-price activities will be used to react to changes in market conditions. For example, Andersen and Toulemonde (2004) explore how a presence of both cost of price adjustment and cost of quantity adjustment, determines which-the price or the quantity—will be the chosen as a margin of adjustment. Danziger (2001) uses a similar framework to assess the welfare implications of inflation.

In a more recent study, Levy and Young (2006) try to assess the implications of a simultaneous presence of costs of adjusting price, cost of adjusting quality, and cost of adjusting quantity, in the context of the Coca-Cola nickel price strategy during the 18861959 period. Levy and Young (2006) document that during this period the Coca-Cola Company chose to keep fixed note only the coke's price (at 5\$), but also its quality. That is, the company tried and was fairly successful in keeping the Coca-Cola's secret formula unchanged. Instead, the Company chose to pursue a strategy of adjusting the Coke's quantity.

These studies of non-price adjustment mechanisms are only the beginning. More work remains to be done. 


\section{ACKNOWLEDGEMENTS}

We are grateful to the referee for useful comments and suggestions. We are thankful also to the participants at the NBER-CRIW conference in Cambridge, MA, and the Price Rigidity Session participants at the American Economic Association Meetings for comments. We are particularly grateful to Walter Oi, the discussant at the NBER-CRIW conference, and to John Carlson, the discussant at the AEA meetings, for insightful comments and suggestions. We also thank Bob Chirinko, Hashem Dezhbakhsh, Jurek Konieczny, Akshay Rao, Sourav Ray, as well as the Economics Seminar participants at Emory University and the Marketing Seminar participants at Harvard University and University of Minnesota, for useful comments and discussions. Finally, we thank the University of Chicago and Dominick’s for providing access to their data set. All authors contributed equally: we rotate co-authorship. The usual disclaimer applies. 


\section{REFERENCES}

Andersen T, Toulemonde E. 2004. Adapting prices or quantities in the presence of adjustment costs. Journal of Money, Credit and Banking 36: 177-196.

Ball L, Mankiw NG. 1994. Asymmetric price adjustment and economic fluctuations. Economic Journal 104: 247-261.

Ball L, Mankiw NG. 1995. Relative price changes as aggregate supply shocks. Quarterly Journal of Economics 110: 161-93.

Ball L, Romer D. 1991. Sticky prices as coordination failure. American Economic Review 81: 539-552.

Barsky R., Bergen M, Dutta S, Levy D. 2003. What can the price gap between branded and private label products tell us about markups. In Scanner Data and Price Indexes, edited by Robert Feenstra and Matthew Shapiro, NBER (Studies in Income and Wealth, Volume 64), Chicago, IL: the University of Chicago Press, 2003, pp. 165-225.

Bedrossian A, Moschos D. 1988. Industrial structure, concentration, and the speed of price adjustment. Journal of Industrial Economics 36: 459-475.

Bergen M, Levy D, Ray S, Rubin P, Zeliger B. 2006. When little things mean a lot: on the inefficiency of item pricing laws. Manuscript presented at the August 1-2, 2003 NBER Law and Economics Program Meeting, Cambridge, MA.

Bergen M, Ritson M, Dutta S, Levy D, Zbaracki M. 2003. Shattering the myth of costless price changes. European Management Journal 21: 663-669.

Berman B, Evans J. 1995. Retail Management: A Strategic Approach. Prentice-Hall: New Jersey.

Blanchard OJ, Kiyotaki N. 1987. Monopolistic competition and the effects of aggregate demand. American Economic Review 77: 647-666.

Blinder, AS, Canetti ERD, Lebow DE, Rudd JB. 1998. Asking About Prices: A New Approach to Understanding Price Stickiness. Russell Sage Foundation: New York, NY.

Buzzell RD, Quelch J, Salmon WJ. 1990. The costly bargain of trade promotion. Harvard Business Review 68: 141-149.

Caplin A. 1993. Individual inertia and aggregate dynamics. In Optimal Pricing, Inflation, 
and the Cost of Price Adjustment, edited by E. Sheshinski and Y. Weiss. The MIT Press: Cambridge, MA, pp. 19-45.

Caplin A, Leahy J. 1991. State-dependent pricing and the dynamics of money and output. Quarterly Journal of Economics 106: 683-708.

Caplin A, Leahy J. 1995. The economics of adjustment. In The Natural Rate of Unemployment, edited by Rod Cross. Cambridge University Press: New York, NY.

Caplin A, Spulber DF. 1987. Menu costs and the neutrality of money. Quarterly Journal of Economics 102: 703-725.

Carlton DW. 1983. Equilibrium fluctuations when price and delivery lag clear the market. Bell Journal of Economics 14: 562-572.

Carlton DW. 1985. Delivery lags as a determinant of demand. Unpublished manuscript.

Carlton DW. 1986. The rigidity of prices. American Economic Review 76: 637-658.

Carlton DW. 1989. The theory and the facts of how markets clear: is industrial organization valuable for understanding macroeconomics? In Handbook of Industrial Organization, Volume 1, edited by R. Schmalensee and R.D. Willig. North Holland: Amsterdam, pp. 909-46.

Carlton DW, Perloff JM. 1994. Modern Industrial Organization. Harper Collins: New York, NY.

Caucutt EM, Ghosh M, Kelton CML. 1995. Durability versus concentration as an explanation for price inflexibility. Review of Industrial Organization 14: 27-50.

Chevalier J, Kashyap A, Rossi P. 2003. Why don’t prices rise during periods of peak demand? Evidence from scanner data. American Economic Review 93: 15-37.

Clay K, Krishnan R, Wolff E, Fernandes D. 2002. "Retail strategies on the web: price and non-price competition in the online book industry. Journal of Industrial Economics 50: 351-367.

Danziger L. 1999. A dynamic economy with costly price adjustment. American Economic Review 89: 878-901.

Danziger L. 2001. Output and welfare effects of inflation with price and quantity adjustment costs. American Economic Review 91: 1608-1620.

Domberger S. 1979. Price adjustment and market structure. The Economic Journal 89: 96-108. 
Dutta S, Bergen M, Levy D. 2002. Price flexibility in channels of distribution: evidence from scanner data. Journal of Economic Dynamics and Control 26: 1845-1900.

Dutta S, Bergen M, Levy D, Venable R. 1999. Menu costs, posted prices, and multiproduct retailers. Journal of Money, Credit, and Banking 31: 683-703.

Economides N. 1998. The incentive for non-price discrimination by an input monopolist. International Journal of Industrial Organization 16: 271-284.

Epstein G. 2006. Production, inventory and waiting costs. Managerial and Decision Economics, forthcoming.

Geroski PA. 1992. Price dynamics in UK manufacturing: a microeconomic view. Economica 59: 403-419.

Gordon RJ. 1990. What is New-Keynesian economics? Journal of Economic Literature 28: $1115-1171$.

Hammer PJ. 1999. Questioning traditional antitrust presumptions: price and non-price competition in hospital markets. University of Michigan Journal of Law Reform 32: 727-783.

Hannan TH, Berger AN. 1991. The rigidity of prices: evidence from the banking industry. American Economic Review 81: 938-945.

Kahn B. McAlister L. 1997. Grocery Revolution: The New Focus on The Consumer. Addison-Wesley: Boston, MA.

Levy D.1999. Daniel Levy looks close to 'home' to examine markets. Emory Report (First Person Column) 51: p. 2.

Levy D, Bergen M, Dutta S, Venable R. 1997. The magnitude of menu costs: direct evidence from large U.S. supermarket chains. Quarterly Journal of Economics 112: 791-825.

Levy D, Dutta S, Bergen M. 2002. Heterogeneity in price rigidity: evidence from a case study using micro-level data. Journal of Money, Credit and Banking 34: 197-220.

Levy D, Dutta S, Bergen M, Venable R. 1998. Price adjustment at multiproduct retailers. Managerial and Decision Economics 19: 81-120.

Levy D, Young AT. 2004. 'The real thing:' nominal price rigidity of the nickel coke, 1886-1959. Journal of Money, Credit and Banking 36: 765-799.

Levy D, Young AT. 2006. Adjusting price or adjusting quantity? Surprising evidence. 
manuscript in preparation.

Levy M, Weitz BA. 2001. Retailing Management, 4th edition. McGraw-Hill/Irwin: New York, NY.

Mankiw NG. 1985. Small menu costs and large business cycles: a macroeconomic model. Quarterly Journal of Economics 100: 529-538.

Müller G, Bergen M, Dutta S, Levy D. 2006. Private label price rigidity during holiday periods. Applied Economics Letters 13: 57-62.

Müller G, Levy D, Dutta S, Bergen M. 2005. Holiday price rigidity and cost of price adjustment. Bar-Ilan University and Emory University Working Paper.

Neumark D, Sharpe SA. 1993. Market structure and the nature of price rigidity: evidence from the market for consumer deposits. Quarterly Journal of Economics 108: 657680.

Oliver JM, Farris PW. 1989. Push and pull: a one-two punch for packaged products. Sloan Management Review Fall: 53-61.

Pashigian BP, Bowen B. 1991. Why are products sold on sale? Explanations of pricing regularities. Quarterly Journal of Economics 106: 1015-1038.

Rotemberg JJ. 1982. Sticky prices in the United States. Journal of Political Economy 110: 1187-211.

Slade ME. 1998. Optimal pricing with costly adjustment: evidence from retail-grocery prices. Review of Economic Studies 65: 87-107.

Warner EJ, Barsky R. 1995. The timing and magnitude of retail store markdowns: evidence from weekends and holidays. Quarterly Journal of Economics 110: 321352.

Symeonidis, GP. 2000. Competition, non-price competition and market structure: theory and evidence from the UK. Economica 67: 437-456.

Young A, Levy D. 2006. Explicit evidence on an implicit contract. Bar-Ilan University and Emory University Working Paper.

Zbaracki M, Bergen M, Levy D. 2006. The anatomy of a price cut: discovering organizational sources of the costs of price adjustment. Bar-Ilan University and Emory University Working Paper.

Zbaracki M, Ritson M, Levy D, Dutta S, Bergen M. 2004. Managerial and customer costs 
of price adjustment: direct evidence from industrial markets. Review of Economics and Statistics 86: 514-533. 
Table 1. Product Categories and Number of Products

\begin{tabular}{c|lr}
\hline No. & \multicolumn{1}{|c}{$(1)$} & $(2)$ \\
& Product Category & Number of Products \\
\hline 1 & Analgesics & 1,362 \\
2 & Bottled Juices & 1,578 \\
3 & Cereals & 1,740 \\
4 & Cheeses & 2,262 \\
5 & Crackers & 822 \\
6 & Canned Soups & 1,824 \\
7 & Dish Detergents & 1,086 \\
8 & Frozen Entrees & 3,306 \\
9 & Frozen Juices & 702 \\
10 & Fabric Softeners & 1,176 \\
11 & Laundry Detergents & 2,160 \\
12 & Paper Towels & 510 \\
13 & Refrigerated Juices & 672 \\
14 & Soft Drinks & 3,666 \\
15 & Snack Crackers & 1,368 \\
16 & Canned Fish & 1,008 \\
17 & Tooth Pastes & 1,530 \\
18 & Toilet Tissues & 420 \\
\hline & Total & 27,192 \\
\hline
\end{tabular}

Note: The figures are for all six sampled stores combined. See the text for details. 
Table 2. Logit Model Estimation Results

\begin{tabular}{|c|c|c|c|c|}
\hline Product Category & $\beta$ & $p$-value & $\delta$ & $p$-value \\
\hline Analgesics & -0.6002 & .0200 & -2.3366 & .0001 \\
\hline Bottled Juices & -2.1513 & .0001 & -2.1474 & .0001 \\
\hline Cereals & -1.6539 & .0001 & -1.8084 & .0001 \\
\hline Cheeses & -1.3348 & .0001 & -1.6034 & .0001 \\
\hline Crackers & -1.1493 & .0060 & -1.8600 & .0015 \\
\hline Canned Soups & -2.0955 & .0001 & -1.3807 & .0001 \\
\hline Dish Detergents & -1.7931 & .0004 & -1.7874 & .0004 \\
\hline Frozen Entrees & -1.1581 & .0001 & -1.1562 & .0001 \\
\hline Frozen Juices & -2.6994 & .0072 & -1.0429 & .0228 \\
\hline Fabric Softeners & -0.7157 & .0168 & -1.2802 & .0009 \\
\hline Laundry Detergents & -0.8464 & .0003 & -0.7412 & .0008 \\
\hline Paper Towels & 1.0178 & .0001 & 1.0346 & .0001 \\
\hline Refrigerated Juices & -0.2714 & .4148 & -0.6504 & .0968 \\
\hline Soft Drinks & -1.8520 & .0001 & -2.3987 & .0001 \\
\hline Snack Crackers & -1.8041 & .0001 & -1.7996 & .0001 \\
\hline Canned Fish & -0.8935 & .0093 & -1.7323 & .0006 \\
\hline Tooth Pastes & -1.9083 & .0001 & -0.9111 & .0014 \\
\hline Toilet Tissues & -2.2243 & .0273 & -1.5003 & .0368 \\
\hline
\end{tabular}

Note: The estimated models are:

$$
\log \left(\frac{p_{t}}{1-p_{t}}\right)=\alpha+\beta \text { Holiday }_{t},
$$

for product introductions, where $p$ denotes the probability of a product introduction, and

$$
\log \left(\frac{p_{t}}{1-p_{t}}\right)=\gamma+\delta \text { Holiday }_{t},
$$

for product deletions, where $p$ denotes the probability of a product deletion. In both specifications, the variable "Holiday" is a dummy variable attaining the value 1 if the week falls in the Thanksgiving-Christmas holiday period and 0 otherwise. See the text for more details. 
Table 3. Percentage of the Actual Number of Products Introduced and Deleted during Holidays in Comparison to Even Odds

\begin{tabular}{|c|c|c|c|c|c|c|c|c|}
\hline Category & $\begin{array}{c}\text { (1) } \\
\text { Total } \\
\text { number of } \\
\text { products } \\
\text { introduced } \\
\end{array}$ & $\begin{array}{c}\text { (2) } \\
\text { Total number } \\
\text { of holiday } \\
\text { introductions }\end{array}$ & $\begin{array}{c}\text { (3) } \\
\text { Total } \\
\text { number of } \\
\text { products } \\
\text { deleted } \\
\end{array}$ & $\begin{array}{c}\text { (4) } \\
\text { Total umber } \\
\text { of holiday } \\
\text { deletions }\end{array}$ & $\begin{array}{l}\text { (5) } \\
\text { \% products } \\
\text { introduced } \\
\text { in holidays }\end{array}$ & $\begin{array}{c}(6) \\
t \text {-statistic for } \\
\text { introductions } \\
\text { (even odds = } \\
0.1154 \text { ) }\end{array}$ & $\begin{array}{c}(7) \\
\% \text { products } \\
\text { deleted in } \\
\text { holidays }\end{array}$ & $\begin{array}{c}(8) \\
t \text {-statistic for } \\
\text { deletions } \\
\text { (even odds = } \\
0.1154 \text { ) }\end{array}$ \\
\hline Analgesics & 153 & 13 & 132 & 2 & 0.08 & $-1.35^{\mathrm{c}}$ & 0.02 & $-9.43^{a}$ \\
\hline Bottled Juices & 171 & 3 & 173 & 2 & 0.02 & $-9.75^{a}$ & 0.01 & $-12.78^{a}$ \\
\hline Cereals & 178 & 8 & 182 & 3 & 0.04 & $-4.54^{a}$ & 0.02 & $-10.48^{a}$ \\
\hline Cheeses & 195 & 15 & 185 & 5 & 0.08 & $-2.02^{\mathrm{b}}$ & 0.03 & $-7.41^{\mathrm{a}}$ \\
\hline Crackers & 90 & 6 & 83 & 3 & 0.07 & $-1.85^{b}$ & 0.04 & $-3.87^{a}$ \\
\hline Canned Soups & 138 & 4 & 138 & 4 & 0.03 & $-6.05^{a}$ & 0.03 & $-6.05^{a}$ \\
\hline Dish Detergents & 128 & 4 & 121 & 2 & 0.03 & $-5.47^{a}$ & 0.02 & $-8.53^{a}$ \\
\hline Frozen Entrees & 349 & 19 & 339 & 12 & 0.05 & $-5.02^{a}$ & 0.04 & $-7.97^{a}$ \\
\hline Frozen Juices & 72 & 1 & 66 & 2 & 0.01 & $-7.36^{\mathrm{a}}$ & 0.03 & $-4.03^{\mathrm{a}}$ \\
\hline Fabric Softeners & 131 & 4 & 126 & 4 & 0.03 & $-5.65^{a}$ & 0.03 & $-5.36^{a}$ \\
\hline Laundry Detergents & 276 & 20 & 263 & 10 & 0.07 & $-2.75^{a}$ & 0.04 & $-6.56^{a}$ \\
\hline Paper Towels & 58 & 23 & 59 & 25 & 0.40 & 4.38 & 0.42 & 4.79 \\
\hline Refrigerated Juices & 70 & 5 & 71 & 4 & 0.07 & $-1.43^{\mathrm{c}}$ & 0.06 & $-2.16^{b}$ \\
\hline Soft Drinks & 402 & 13 & 372 & 6 & 0.03 & $-9.41^{\mathrm{a}}$ & 0.02 & $-15.20^{\mathrm{a}}$ \\
\hline Snack Crackers & 134 & 5 & 130 & 1 & 0.04 & $-4.77^{a}$ & 0.01 & $-14.06^{a}$ \\
\hline Canned Fish & 101 & 9 & 89 & 1 & 0.09 & -0.93 & 0.01 & $-9.32^{\mathrm{a}}$ \\
\hline Tooth Pastes & 172 & 3 & 168 & 9 & 0.02 & $-9.81^{\mathrm{a}}$ & 0.05 & $-3.56^{a}$ \\
\hline Toilet Tissues & 42 & 1 & 41 & 1 & 0.02 & $-3.89^{a}$ & 0.02 & $-3.78^{a}$ \\
\hline Total & 2,860 & 156 & 2,738 & 96 & 0.05 & $-14.33^{a}$ & 0.04 & $-22.85^{a}$ \\
\hline
\end{tabular}

Note: The superscripts a, b, and c, indicate a statistical significance at $1 \%, 5 \%$, and $10 \%$, respectively. 
Table 4. Percentage of the Actual Number of Pre-priced Products Introduced and Deleted during Holidays in Comparison to Even Odds

\begin{tabular}{|c|c|c|c|c|c|c|c|c|}
\hline Category & $\begin{array}{c}(1) \\
\text { Total } \\
\text { number of } \\
\text { products } \\
\text { introduced } \\
\end{array}$ & $\begin{array}{c}\text { (2) } \\
\text { Total number } \\
\text { of holiday } \\
\text { introductions }\end{array}$ & $\begin{array}{c}\text { (3) } \\
\text { Total } \\
\text { number of } \\
\text { products } \\
\text { deleted } \\
\end{array}$ & $\begin{array}{c}\text { (4) } \\
\text { Total umber } \\
\text { of holiday } \\
\text { deletions }\end{array}$ & $\begin{array}{l}\text { (5) } \\
\% \text { products } \\
\text { introduced } \\
\text { in holidays }\end{array}$ & $\begin{array}{c}(6) \\
t \text {-statistic for } \\
\text { introductions } \\
\text { (even odds = } \\
0.1154 \text { ) }\end{array}$ & $\begin{array}{c}(7) \\
\text { \% products } \\
\text { deleted in } \\
\text { holidays }\end{array}$ & $\begin{array}{c}(8) \\
t \text {-statistic for } \\
\text { deletions } \\
\text { (even odds = } \\
0.1154 \text { ) }\end{array}$ \\
\hline Analgesics & 1 & 0 & 2 & 0 & - & - & - & - \\
\hline Cheeses & 3 & 1 & 3 & 0 & 0.33 & 0.80 & - & - \\
\hline Dish Detergents & 20 & 1 & 20 & 1 & 0.05 & $-1.34^{\mathrm{c}}$ & 0.05 & $-1.34^{c}$ \\
\hline Fabric Softeners & 11 & 0 & 12 & 0 & - & - & - & - \\
\hline Laundry Detergents & 51 & 5 & 50 & 3 & 0.10 & -0.42 & 0.06 & $-1.65^{b}$ \\
\hline Paper Towels & 10 & 1 & 9 & 2 & 0.10 & -0.16 & 0.22 & 0.77 \\
\hline Soft Drinks & 34 & 1 & 24 & 1 & 0.03 & $-2.97^{a}$ & 0.04 & $-1.81^{\mathrm{b}}$ \\
\hline Toilet Tissues & 2 & 0 & 2 & 0 & - & - & - & - \\
\hline Total & 132 & 9 & 122 & 7 & 0.07 & $-2.15^{a}$ & 0.06 & $-2.76^{\mathrm{a}}$ \\
\hline
\end{tabular}

Note: The superscripts a, b, and c, indicate a statistical significance at $1 \%, 5 \%$, and $10 \%$, respectively. 


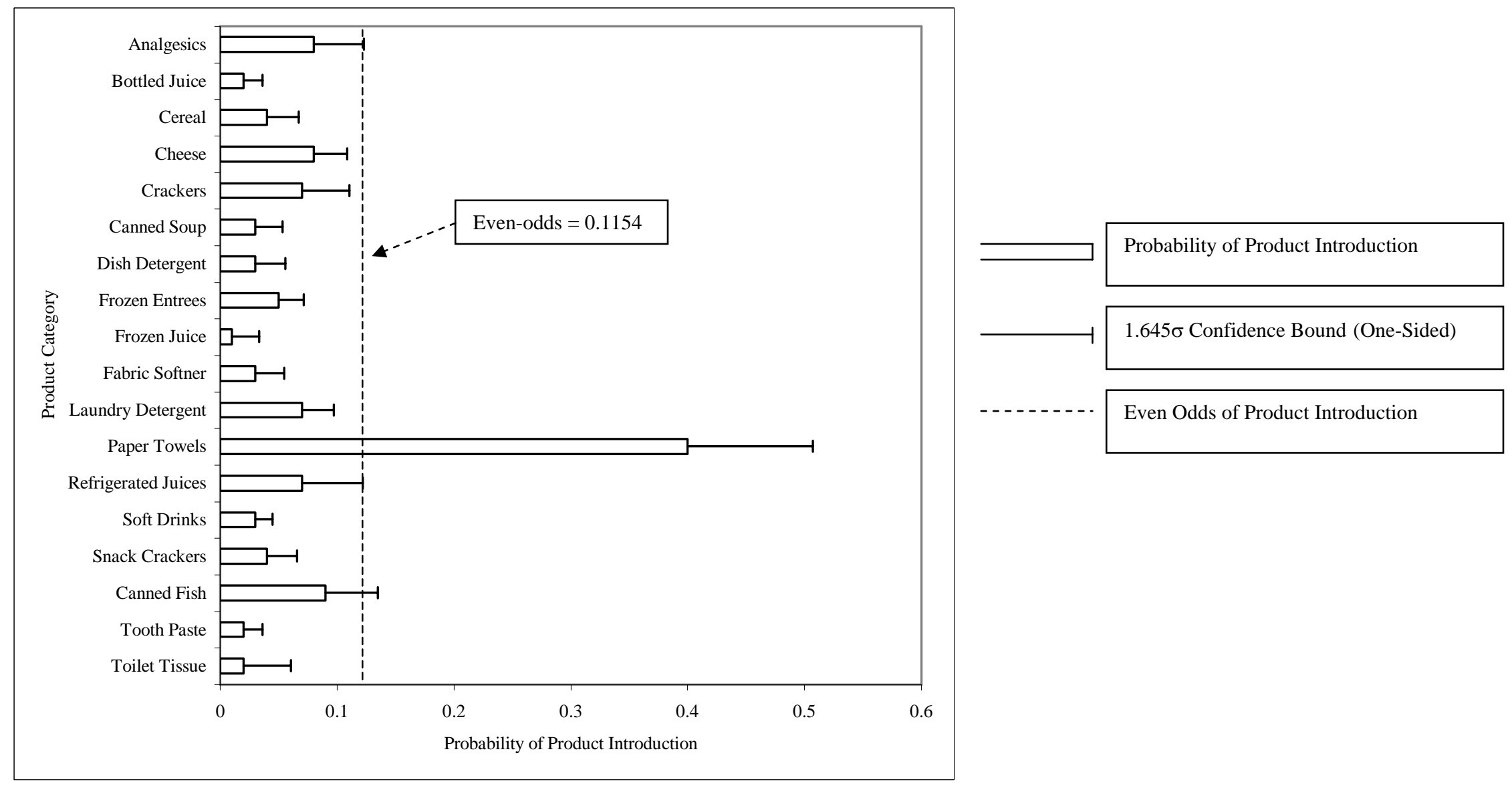

Figure 1. Actual Probability of Product Introduction versus Even Odds 

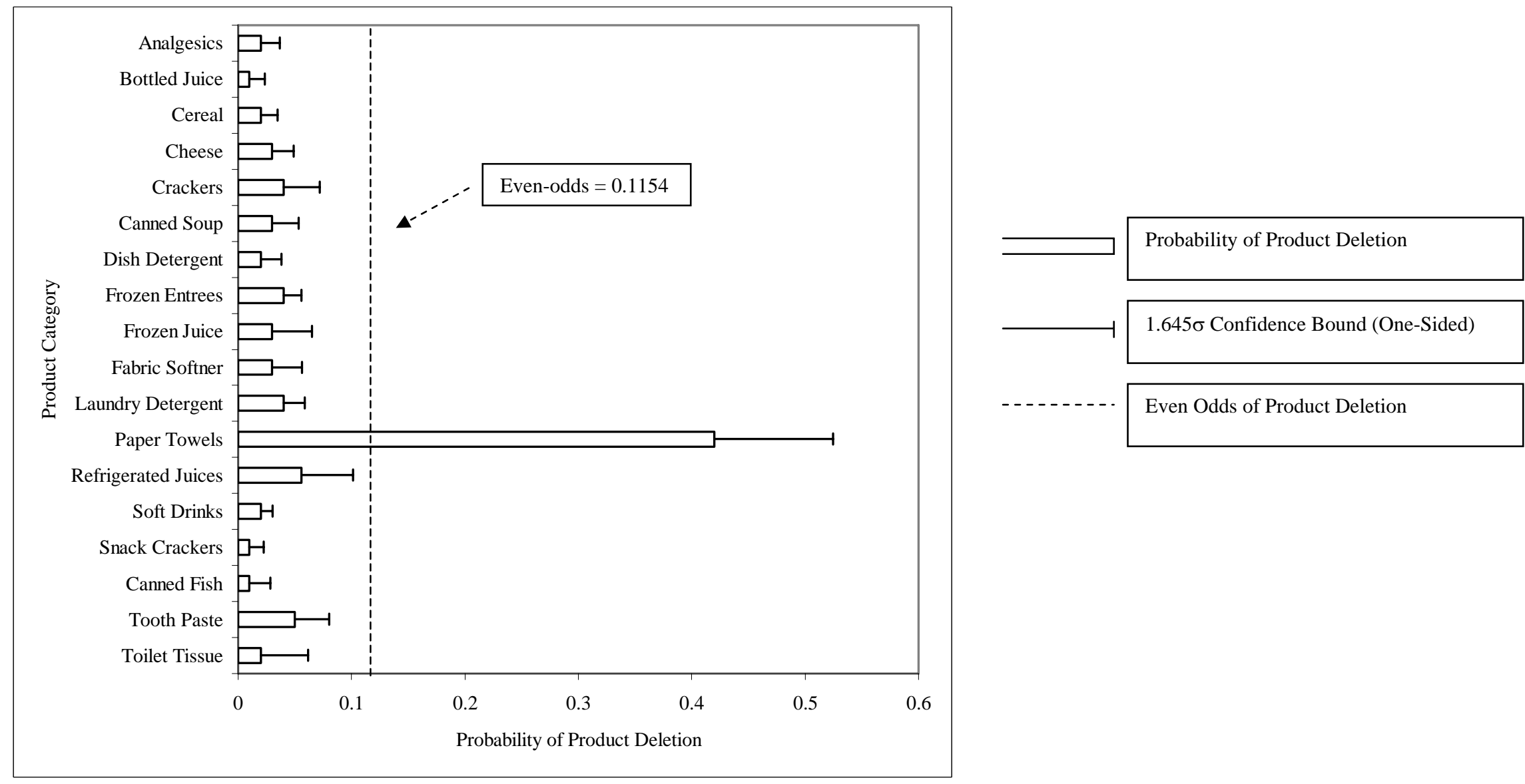

Figure 2. Actual Probability of Product Deletion versus Even Odds 